\title{
Growth Performance and Field Evaluation of Herbicide-Resistant Transgenic Creeping Bentgrass
}

\author{
Ki-Won Lee ${ }^{1}$, Byung-Hyun Lee ${ }^{2}$, Bo-Ram $\mathrm{Seo}^{3}$, Jin-Seog $\mathrm{Kim}^{3}$ and Sang-Hoon Lee ${ }^{1 *}$ \\ ${ }^{1}$ Grassland and Forages Division, National Institute of Animal Science, Rural Development Administration, Cheonan, \\ 330-801, Korea, ${ }^{2}$ Division of Applied Life Science (BK21 program), IALS, Gyeongsang National University, \\ Jinju 660-701, Korea, ${ }^{3}$ Korea Research Institute of Chemical Technology, Daejeon, 305-600, Korea
}

\begin{abstract}
This study examined the growth performance and field evaluation of the dual herbicide-resistant transgenic creeping bentgrass plants. The effect of glyphosate treatment on the herbicide resistance of the transgenic creeping bentgrass plants was determined, and the non-transgenic control plant withered at the concentration $11 \mu \mathrm{g} / \mathrm{mL}$ or higher whereas the transgenic creeping bentgrass plants survived the treatment at the concentration of $3,000 \mu \mathrm{g} / \mathrm{mL}$, and the increase of the plant length was repressed as the glyphosate treatment concentration was increased. At field evaluation, glufosinate-ammonium and glyphosate were simultaneously treated to investigate the weed control effect. The results showed that more than $90 \%$ of the weeds withered four week after herbicide treatment, while the transgenic creeping bentgrass plants continued to grow normally. Therefore, the dual herbicideresistant creeping bentgrass plants may be able to greatly contribute to the efficiency of weed control and to the economic feasibility of mowing in places such as golf courses.

(Key words : Creeping bentgrass, Glufosinate-Ammonium, Glyphosate, Herbicide, Transformation)
\end{abstract}

\section{I . INTRODUCTION}

Creeping bentgrass (Agrostis stolonifera L.) planted on green in golf course requires weed control for good grass growth, since it competes with weeds in the entire growth period. On the other hand, creeping bentgrass also requires ceaseless mowing in order to maintain a good green state, because it grows rapidly (Lee et al., 2011).

The development and commercialization of herbicide resistant crops by biotechnology have been focused mainly on nonselective herbicides (glufosinate-ammonium and glyphosate) for corn, cotton, rape (or canola), rice and other crops (Duke, 2005; Dewar, 2009; Shipitalo et al., 2008; Sakiko et al., 2005; Padgette et al., 1995). From the viewpoint of weed control almost all the herbicide resistant crops have an herbicide resistant gene to a single herbicide and include an antibiotic resistance gene as a selection marker (Felsot, 2000).

In this case, there are a few technological problems that need to be solved in the aspects of safety and weed control efficiency. First, transformed crops should be developed not to have an antibiotic marker (Owen and Zelaya, 2005). Second, the appearance of herbicide resistance weed under natural conditions should be repressed as much as possible. Third, the weed control technology should be improved in order to reduce the cost and effort required for weed control. Fourth, the herbicide input to agricultural environment should be minimized.

On the other hand, a considerable amount of maintenance cost is needed for bentgrass planted on green in golf course because it has strong vitality and thus mowing should be performed frequently. Hence, a technology to slow the plant length increase would provide an advantage in the aspect of maintenance because the number of times for mowing could be reduced. The only technology used for the purpose was the treatment of retardant, a plant growth control agent, but it does not have weed control effect.

Therefore, the objective of this study was to develop the dual herbicide-resistant creeping bentgrass plant to which the glufosinate-ammonium and glyphosate herbicides resistant

* Corresponding author: Sang-Hoon Lee, National Institute of Animal Science, Cheonan, 330-801, Korea. Tel.: +82-41-580-6754, E-mail: sanghoon@korea.kr (S.-H Lee) 
genes (bar and CP4-EPSPS) are transferred by the combination of nonselective herbicides, which gives a synergetic weed control effect, to increase the efficiency of weed control and reduce the number of times for mowing by slowing the growth of creeping bentgrass, and thus to perform the weed control and mowing more efficiently on green in golf courses, allowing the mixed treatment or systematic treatment of herbicides at a lower concentration level.

\section{П. MATERIALS AND METHODS}

\section{Plant material}

For efficient weed control, an expression vector to which two herbicide resistance genes were introduced was prepared and transferred into a creeping bentgrass (Lee et al., 2011). With the plant to which the genes were transferred and of which expression was confirmed (Lee et al., 2011), the effect of the herbicide treatment on the growth performance and field evaluation was investigated.

\section{Effect of herbicide treatment on the growth perfor- mance}

To investigate the plant length increase repression effect of the glyphosate treatment on the transformed creeping bentgrass at the whole plant level, the non-transformed control and transformed plants (Line 1, 8, 14 plants) cultivated in a greenhouse. Following three weeks of plant leaves were cut, leaving $4.0 \mathrm{~cm}$ over the ground surface, and then glyphosate (95\% purity, Duchefa) was sprayed on the leaf, $2.5 \mathrm{ml}$ per round pot of $64 \mathrm{~cm}^{2}$, at five different concentrations from $1 \mu \mathrm{g} / \mathrm{mL}$ to $3,000 \mu \mathrm{g} / \mathrm{mL}$. Withering and plant length increase were investigated and compared after 24 days.

Additionally, glyphosate of 20, 80 and $320 \mu \mathrm{g} / \mathrm{mL}$ was treated to investigate the shikimate accumulation in the transformed creeping bentgrass plant depending on the glyphosate treatment concentrations (Lee et al., 2011 Kim et al., 2008).

3. Field evaluation of herbicide-resistant transgenic creeping bentgrass
To verify the resistance to the two herbicides under natural environmental conditions, a $2 \times 3 \mathrm{~m}\left(6 \mathrm{~m}^{2}\right)$ field was formed and the plant were transplanted and cultivated in a $25 \mathrm{~cm}$ interval. The tolerance to the herbicides in the field was tested by treating the mixture of $0.5 \%$ Basta and $500 \mu$ $\mathrm{g} / \mathrm{mL}$ glyphosate after eight weeks of cultivation.

\section{RESULTS AND DISCUSSION}

\section{Production of transgenic creeping bentgrass}

The DNA, RNA and proteins were isolated from the transformed creeping bentgrass plant to which the genes resistant to the two herbicides were transferred. The transfer of the genes to the genome was verified by Sothern analysis and the stable expression by Northern analysis. The tolerance of the plants to which the genes resistant to the two herbicides were transferred was tested in vitro and the result showed that the plant had the resistance to the two herbicides (Lee et al., 2011). The lines with excellent herbicide tolerance were transplanted to the GM isolated field and cultivated. There was no difference between the transformed plants and the non-transformed plants under the normal cultivation conditions without herbicide treatment (Fig. 1).
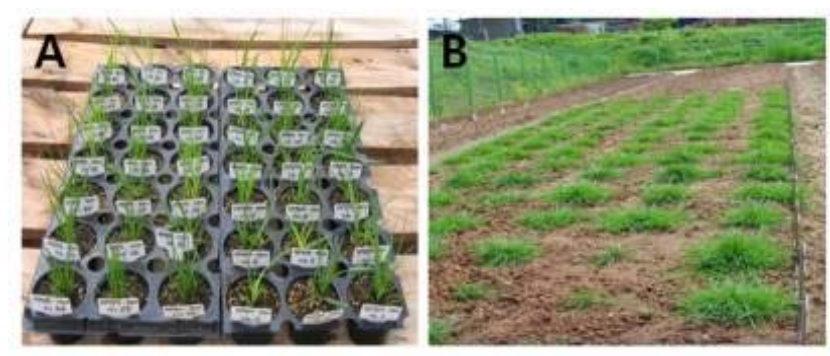

Fig. 1. Different developmental stages of transgenic creeping bentgrass through via Agrobacteriummediated transformation; $A$, Phenotypes of the p35S-EPSPS-B (TP) transgenic creeping bentgrass plants under normal growth condition.; B, Field performance of p35S-EPSPS-B-transgenic creeping bentgrass plants to environmental condition.

2. Repression of plant length increase in transformed creeping bentgrass by glyphosate treatment

The result showed that the non-transformed control plants 
withered at the concentration $11 \mu \mathrm{g} / \mathrm{mL}$ or higher whereas the transformed plant bodies survived the treatment at the concentration of $3,000 \mu \mathrm{g} / \mathrm{mL}$. However, the increase of the plant length was repressed as the glyphosate treatment concentration was increased, the plant length increase at $1,000 \mu \mathrm{g} / \mathrm{mL}$ glyphosate treatment was $25 \%$ of that of the non-treated group (Fig. 2). This may give a great advantage in the economical maintenance of bentgrass in places such as golf courses because the plant length increase is significantly repressed without withering by the herbicide treatment, thereby creating the situation not require frequent mowing.

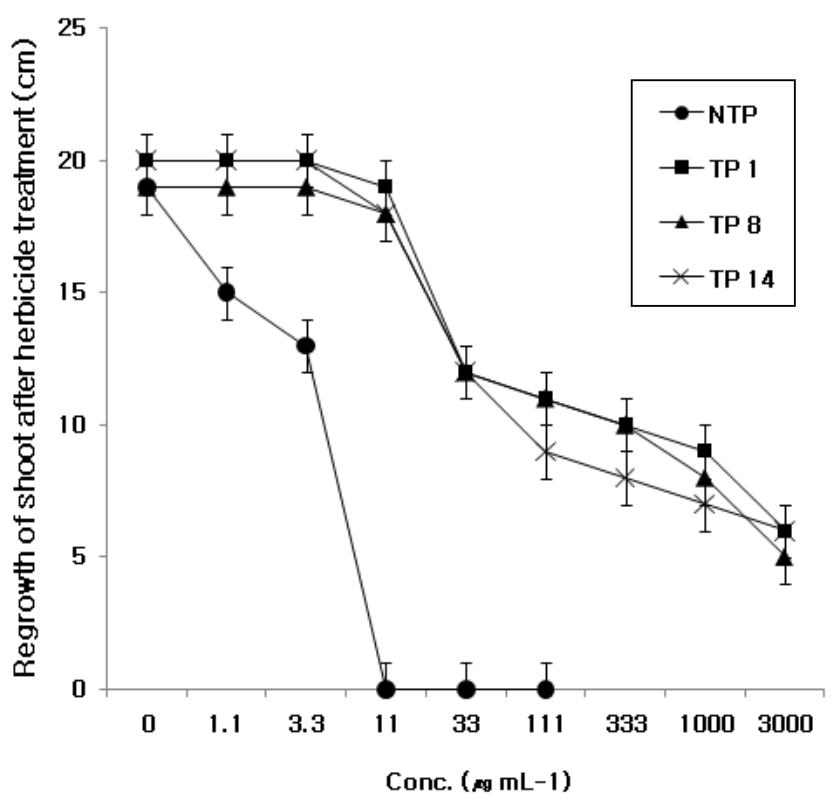

Fig. 2. Shoot regrowth of non-transgenic (NTP) and transgenic (TP) bentgrass treated with different dosage of glyphosate.

\section{Accumulation of shikimate in the transgenic} creeping bentgrass

CP4-EPSPS, the gene isolated from Agrobacterium sp CP4 line, shows a significant tolerance to glyphosate (Dill, 2005). Hence, the transfer of CP4-EPSPS into a crop and overexpression of it allows normal biosynthesis of aromatic amino acids without being greatly affected by glyphosate. However, if CP4-EPSPS is not transferred, the EPSPS in the plant body will be repressed by glyphosate, the biosynthesis of aromatic amino acids will be repressed and thus shikimate will be accumulated in the plant body (Kim et al., 2008). Table 1 shows the shikimate accumulation result in the transformed creeping bentgrass plant body depending on the glyphosate treatment concentration. It was found that the shikimate accumulation in the herbicide resistance creeping bentgrass plant body was dependent upon the herbicide concentration. Thus, shikimate accumulation test may be useful to verify the transformed plant body to which EPSPS gene is transferred.

Table 1. Effect of Glyphosate concentration on shikimate level in leaf segments from field grown plants

\begin{tabular}{ccc}
\hline \multirow{2}{*}{$\begin{array}{c}\text { Glyphosate } \\
(\mathrm{ug} / \mathrm{mL})\end{array}$} & \multicolumn{2}{c}{ Shikimate accumulation (A380) } \\
\cline { 2 - 3 } & Wild type* & $\begin{array}{c}\text { Transgenic plant } \\
\text { (TP1)* }\end{array}$ \\
\hline \hline 20 & $0.406 \pm 0.039$ & $0.221 \pm 0.019$ \\
80 & $0.570 \pm 0.054$ & $0.278 \pm 0.017$ \\
320 & $0.595 \pm 0.038$ & $0.295 \pm 0.039$ \\
\hline
\end{tabular}

* Values represent the mean \pm standard deviation (SD) of three independent experiments.

\section{Tolerance test in $\mathrm{GM}$ isolated field}

To test the tolerance to the herbicides in the GM isolated field, the mixture of $0.5 \%$ Basta and $500 \mu \mathrm{g} / \mathrm{mL}$ glyphosate was sprayed on the eighth week of the cultivation for weed control. The result showed that the weeds gradually withered from the seventh day after the treatment, more than $50 \%$ of the weeds withered after two weeks, and more than $90 \%$ after four weeks. On the contrary, the transformed plant did not get any chemical injury, growing in good condition (Fig. 3).
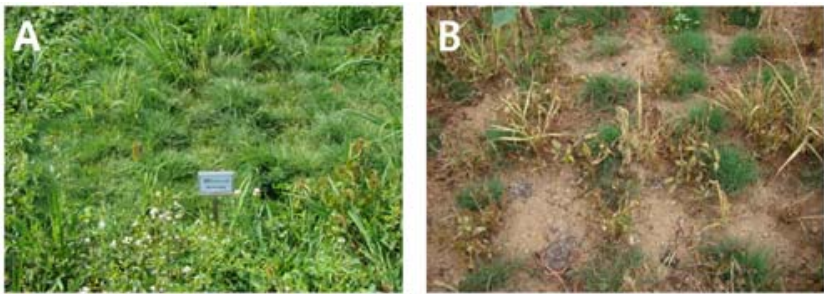

Fig. 3. Field trials for herbicide resistance of transgenic creeping bentgrass line (TP1). A plots before spraying; $B$ resistance of transgenic after four weeks after spraying (0.5\% Basta and 500 $\mu \mathrm{g} / \mathrm{mL}$ Glyphosate). 


\section{CONCLUSIONS}

Biotechnology technique has been widely adapted to improve the quality and quantity of various varieties of crop plants by manipulations of useful genetic materials. However, still wide range of grass varieties has not been developed for gene transfer technology and useful genetic materials needs to identify. Here, we suggest that one of famous field grass on golf course, creeping bentgrass, have developed for transgenic plants harboring two herbicide resistant genes, bar and CP4-EPSPS. When two herbicides (glufosinate-ammonium and glyphosate) were treated independently or together, transgenic creeping bentgrass showed healthy growth and better survivability even in the presence of excessive concentrations of herbicide. However, the plant growth of transgenic creeping bentgrass was repressed with increasing of glyphosate concentration showing only $25 \%$ compared to the non-herbicide treated plants. It suggests that controlling of herbicide concentrations may reduce the plant growth of transgenic creeping bentgrass plants. If the transgenic creeping bentgrass could applied to golf field, it provides the great advantages having reduced number of times for mowing and weed control on golf field.

\section{REFERENCES}

Dill, G.M. 2005. Glyphosate-resistant crops: history, status and future. Pest Management Science. 61:219-224.
Duke, S.O. 2005. Taking stock of herbicide-resistant crops ten years after introduction. Pest Management Science. 61:211-218.

Dewar, A.M. 2009. Weed control in glyphosate-tolerant maize in Europe. Pest Management Science. 65:1047-1058.

Felsot, A.S. 2000. Herbicide tolerant genes: Part 1: Squaring up roundup ready crops. Agri-chemical and Environmental News. 173:8-15

Kim, J.S., Choi, J.S., Seo, B.R. and Hwang, H.J. 2008. Characteristics of shikimate accumulation in various plants treated with glyphosate. Korean Journal of Weed Science. 28:264-273.

Lee, K.W., Kim, K.Y., Kim, K.H., Lee, B.H., Kim, J.S. and Lee, S.H. 2011. Development of antibiotic marker-free creeping bentgrass resistance against herbicides. Acta Biochimica et Biophysica Sinica. 43:13-18.

Owen, M.D. and Zelaya, I.A. 2005. Herbicide-resistant crops and weed resistance to herbicides. Pest Management Science. 61: 301-311.

Padgette, S.R., Kolacz, K.H. and Delannay, X. 1995. Development, identification, and characterization of a glyphosate-tolerant soybean line. Crop Science. 35:1451-1461.

Shipitalo, M.J., Malone, R.W. and Owens, L.B. 2008. Impact of glyphosate-tolerant soybean and glufosinate-tolerant corn production on herbicide losses in surface tunoff. Journal of Environmental Quality. 37:401-408.

Sakiko, H., Hiroyuki, K., Tomomi, I., Hideyuki, I., Hideo, O. and Yasunobu, O. 2005. Enhanced expression of CYP2C9 and tolerance to sulfonylurea herbicides in transgenic rice plants. Plant Biotechnology. 22:89-96.

(Received August 1, 2013 / Revised September 3, 2013/Accepted September 10, 2013) 